\title{
PHYSICALITY AS A POSSIBLE KEY TO UNDERSTANDING HUMAN NATURE
}

\author{
A FISICALIDADE COMO POSSÍVEL CHAVE PARA COMPREENDER ANATUREZA \\ HUMANA
}

\author{
A FISICALIDADE COMO POSSÍVEL CHAVE PARA COMPREENDER A NATUREZA \\ HUMANA
}

Zulfiya Z. IBRAGIMOVA ${ }^{1}$

\begin{abstract}
The statement about human nature is the subject of numerous discussions, which, however, does not negate the presence of the substrate of its origin, manifestations, specificity, and real dynamics in space and time. In the process of analysis, we find a lot of arguments that confirm this fact, as well as a decent number of counterarguments. In this article, a priori, we proceed from the validity of the existence of the term "human nature", recognizing its ambiguity. Of course, our stated physicality as an aspect of human nature does not exhaust the idea of his nature. The nominal division into soul, spirit, etc. gives us some methodological tools. No more than that. Physicality, in its turn, requires problematization. "Physicality "is a category that denotes what a given human body naturally becomes in the course of its social modifications, so this category can certainly not be considered outside of conjunction with another very important category - "spirituality". These concepts, as well as the phenomena they denote, are interrelated (MORGAN 2006). In our review, there are three main ways to interpret "Physicality". Firstly, it is the only factuality that initially claims the ontological status. Secondly, it is part of a harmonious whole that includes all non-corporeal things. I would like to focus on the third aspect, which includes at least three principles. Thirdly, physicality changes its seemingly simple "fate" dramatically, turning into a problem as a way of human existence. This can be interpreted "as a creative act of overcoming oneself". Only this overcoming of the present self presupposes a reliance on its relevance and reality. This ontologically conditioned event is always self-based. In this sense, the body as a creative phenomenon " never appears just by its own. Yet it is precisely overcoming that is the constitutive feature of human existence. A man is bigger than himself. We can say that the problem is a way of human existence. The problem in the most primitive form can be expressed as "I already want to, but I can't yet". Where does the desire come from if the object of desire (the desired situation) is not yet available? How can you want something that doesn't exist yet and never has? The man himself is a few steps ahead (BUBLIK, 2006). Human rationality is based not only on reflectivity, but also on the ability of a person to operate with ideas that do not have objective visibility (for example, the ultimate category of being). Thus, man proves his metaphysicality: "man's metaphysics expresses not only the presence of the supernatural dimension in man but also his ability to determine himself, to be his own creation". The main methods used in writing the article: the unity of historical and logical, the method of reflection.
\end{abstract}

KEYWORDS: Nature. Physicality. Body. Man. Sport. Doping. Entertainment. Social fact.

${ }^{1}$ Kazan Federal University (KPFU), Kazan - Russia. Associate Professor of the Department of General philosophy of the Institute of social and philosophical Sciences and Mass Communications. ORCID: https://orcid.org/00000001-8648-6096. E-mail: yuldyz@rambler.ru 
RESUMO: A afirmação sobre a natureza humana é objeto de inúmeras discussões, o que, porém, não nega a presença do substrato de sua origem, manifestações, especificidade e dinâmica real no espaço e no tempo. No processo de análise, encontramos muitos argumentos que confirmam esse fato, bem como um número razoável de contra-argumentos. Neste artigo, a priori, partimos da validade da existência do termo "natureza humana", reconhecendo sua ambiguidade. Claro, nossa fisicalidade declarada como um aspecto da natureza humana não esgota a ideia de sua natureza. A divisão nominal em alma, espírito, etc. nos dá algumas ferramentas metodológicas. Não mais do que isso. A fisicalidade, por sua vez, requer problematização. "Fisicalidade" é uma categoria que denota o que um determinado corpo humano naturalmente se torna no decorrer de suas modificações sociais, portanto, essa categoria certamente não pode ser considerada fora da conjunção com outra categoria muito importante - "espiritualidade". Esses conceitos, assim como os fenômenos que denotam, estão inter-relacionados (MORGAN, 2006). Em nossa revisão, existem três maneiras principais de interpretar "Fisicalidade". Em primeiro lugar, é a única factualidade que inicialmente reivindica o status ontológico. Em segundo lugar, é parte de um todo harmonioso que inclui todas as coisas incorpóreas. Gostaria de me concentrar no terceiro aspecto, que inclui pelo menos três princípios. Em terceiro lugar, a fisicalidade muda seu "destino" aparentemente simples de maneira dramática, tornando-se um problema como forma da existência humana. Isso pode ser interpretado "como um ato criativo de superação de si mesmo". Somente essa superação do eu presente que se pressupõe uma confiança em sua relevância e realidade. Este evento ontologicamente condicionado é sempre baseado em si mesmo. Nesse sentido, o corpo como fenômeno criativo "nunca aparece por si só". Mas é justamente a superação que é a característica constitutiva da existência humana. O homem é maior do que ele mesmo. Podemos dizer que o problema é um modo de ser humano. O problema na forma mais primitiva pode ser expresso como "Eu já quero, mas ainda não posso"'. De onde vem o desejo se o objeto de desejo (a situação desejada) ainda não está disponível? Como pode você quer algo que ainda não existe e nunca existiu? O próprio homem está alguns passos à frente (BUBLIK, 2006). A racionalidade humana se baseia não só na refletividade, mas também na capacidade de uma pessoa operar com ideias que não tem visibilidade objetiva (por exemplo, a categoria última do ser). Assim, o homem prova sua metafisicalidade: "a metafísica do homem expressa não só a presença da dimensão sobrenatural no homem, mas também sua capacidade de determinar a si mesmo, de ser sua própria criação". Os principais métodos usados para escrever o artigo são: a unidade histórica e lógica, o método de reflexão.

PALAVRAS-CHAVE: Natureza. Fisicalidade. Corpo. Homem. Esporte. Doping. Entretenimento. Fato social.

RESUMEN: El Enunciado sobre la naturaleza humana es objeto de numerosas discusiones, que, sin embargo, no niega la presencia del sustrato de su origen, manifestaciones, especificidad y dinámicas reales en el espacio y el tiempo. En el proceso de análisis, encontramos muchos argumentos que confirman este hecho, así como un buen número de contraargumentos. En este artículo, a priori, partimos de la vigencia de la existencia del término "naturaleza humana", reconociendo su ambigüedad. Por supuesto, nuestra fisicalidad declarada como un aspecto de la naturaleza humana no agota la idea de su naturaleza. La división nominal en alma, espíritu, etc. nos da algunas herramientas metodológicas. No mas que eso. La fisicalidad, a su vez, requiere problematización. La "fisicalidad" es una categoría que denota lo que un cuerpo humano dado se convierte naturalmente en el curso de sus modificaciones sociales, por lo que esta categoría ciertamente no puede considerarse fuera de 
la conjunción con otra categoría muy importante: la "espiritualidad". Estos conceptos, así como los fenómenos que denotan, están interrelacionados (MORGAN, 2006). En nuestra revisión, hay tres formas principales de interpretar la "fisicalidad". En primer lugar, es la única factualidad que inicialmente reclama el estatus ontológico. En segundo lugar, es parte de un todo armonioso que incluye todas las cosas no corporales. Me gustaría centrarme en el tercer aspecto, que incluye al menos tres principios. En tercer lugar, la fisicalidad cambia dramáticamente su aparentemente simple "destino", convirtiéndose en un problema como una forma de existencia humana. Esto se puede interpretar "como un acto creativo de superación a uno mismo". Solo esta superación del yo presente presupone una confianza en su relevancia y realidad. Este evento condicionado ontológicamente siempre se basa en uno mismo. En este sentido, el cuerpo como fenómeno creativo "nunca aparece por sí solo. Sin embargo, es precisamente la superación lo que constituye el rasgo constitutivo de la existencia humana. Un hombre es más grande que él mismo. Podemos decir que el problema es una forma de El problema en la forma más primitiva puede expresarse como "ya quiero, pero todavía no puedo". ¿De dónde viene el deseo si el objeto del deseo (la situación deseada) aún no está disponible? ¿Quieres algo que aún no existe y nunca ha existido? El hombre mismo está unos pasos por delante (BUBLIK, 2006). La racionalidad humana se basa no solo en la reflectividad, sino también en la capacidad de una persona para operar con ideas que no tener visibilidad objetiva (por ejemplo, la categoría última del ser). Así, el hombre demuestra su metafisica: "la metafisica del hombre expresa no solo la presencia de la dimensión sobrenatural en el hombre sino también su capacidad de determinarse a sí mismo, de ser su propia creación". Los principales métodos utilizados para redactar el artículo: la unidad de lo histórico y lo lógico, el método de la reflexión.

PALABRAS CLAVE: Naturaleza. Físico. Cuerpo. Hombre. Deporte. Dopaje. Capacitación. Hecho social.

\section{Introduction}

In the latest version of the understanding of physicality, the priority of the latter is obvious. In his dialogue Zinchenko V. P. and Podoroga V. A. speak about the fundamental nature of the body and our obvious inability to understand it (SAYKINA, 2014). "I will remind you of Spinoza's words:' what the human body is capable of, no one has yet determined "' (MAMARDASHVILI SENOKOSOV, 2018). Further on the boundlessness of the internal potency of the body the words of M. K. Mamardashvili that "the finite body contains the perfect and infinite" (MAMARDASHVILI, 2002). The last sign for us of self-Foundation, of the fundamental nature of physicality, is the paradox of discovering a spiritual status that is not characteristic of the body. The body becomes an authentic, authenticated identity. For it is rationally planned and created. Corporeality finally gets the desired status of intelligence, and reason-becomes not an ideal activity of consciousness, but a deed-action, as Fichte would say (SOKOLOV, 2001). There is a similar metamorphosis-rationalization in the era of information society, when there is a slightly belated recognition of the body's creative potential, the ability 
to correct the spiritual and personal component. This became possible with the development of scientific knowledge, psychoanalysis, and the transformation of sport into a social fact. Sports teach a person to view their body as an expression of the physical nature, create the illusion of mastering this bodily nature. But the latter makes sense given the spiritual component of human nature. The attitude to the body as a subject of creative forces is not new. Antique actively uses this principle in the implementation Paideia - the creation of man and citizen.

There is a contradictory situation - people acquire a special attitude of ownership of their own body. The transformation of the body into a source of personal enrichment. You can successfully deceive yourself with the illusion of the specificity of your body, but how far is this from the ancient ideal of harmony of body and soul, based on the principles of kalokagathos. On one hand, physical improvement, on the other hand - the trend of successful presentation of your body. There was a powerful commercial motive for extracting money, which is expressed in participation in advertising campaigns. The external factor definitely becomes the leading factor initially. Before British leadership in the 19th century, physical development was woven into the fabric of socialization and collective ethics. In social life, you could be an ordinary citizen, but you were indirectly involved in political processes. The degree of attractiveness turned sports into a special industry. P. Bourdieu, for example, says that there was a transition of educational institutions for representatives of bourgeois society. The body exercises of the "elite" are not related to the usual social circumstances with which folk games remained connected (agricultural festivals, for example), and are devoid of the social (and religious) tasks that were present in many traditional games (for example, ritual games). Today, the use of the body in sports, as well as the use of language in education, is an end in itself (BOURDIEU, 2009).

All that we see now is just the top, open based patriotic, commercial, entertainment arguments. But the formation of a person's worldview is one of the ways to become involved in social and state life. This is one of the forms of developing a person's physicality, but it is also a great way to socialize. But at the same time, in the structure of such socialization, different types of activities can successfully exist: from pharmacology and medicine to the production and use of doping drugs. Not the most worthy case for asserting person's superiority in the world. I don't want to use the word "war", but in reality, the use of doping is not only a violation of the code of sports honor, it is a war of worldviews.

Regarding doping, p. Bourdieu writes (BOURDIEU, 2009). that this is the fate of plebeians, for whom victory at any cost is important... For the elite, winning by the rules is important. The class character of sport is again emphasized... A sporting career is not considered 
an acceptable future for children of the bourgeoisie, but it serves as one of the few channels of vertical mobility open to children from subordinate classes.

How did sport, which had the meaning of entertainment, become an international model of behavior and social fact? Why, in any case, do we see this as a way of realizing the individual? A person becomes physically prepared, able to control himself, overcome everything possible and impossible. This also applies to stress tolerance, which is not typical for all people. These are really the most important skills. Find an activity that can be compared to sports. It seems that no activity can compare with sports. Previously, it was necessary to strengthen the body, the ability to be realized in the military field. Sport was needed so that a warrior, a soldier, could protect the state and his family. It was mainly used by people from the "higher" strata of society (ELIAS, 1971). And they had the opportunity in the future to become a hero who would become part of the ruling power. Today, sport has been part of our life since childhood, revealing the care of our body. That is, by forming a healthy body, we contribute to the formation of a clear intelligence.

\section{Methods}

The method of unity of historical and logical was used in the article to search for the phenomenon of physicality, human nature, ways of mastering human nature. The unity of the historical logical is manifested as a process of correlation of the biological (bodily) and spiritual components of human nature. Historically, these (non-unique) components could only develop in a joint dynamic. Physicality is a visible, obvious and stable backbone of the multi-faceted nature of man, a visual criterion that contributes to understanding the nature of man as a whole. The method of reflection is important for understanding the physicality of human nature "as a whole, aware of its organization, reflection is an ability acquired by consciousness to focus on itself and master itself as an object that has its own specific stability and its own specific meaning-the ability to no longer just to learn, but to learn oneself; not just to know, but to know what you know". The method of reflection allows us to consider the physicality of a person as an imperishable substratum of being. In the article, the physicality of a person is studied as a universal and objective meaning that concentrates various non-corporeal meanings. The basic meaning of corporeality allows us to analyze the various hypostases of human nature. 


\section{Results}

The Problem of human nature, the mastery of its nature is a subject of long-standing disputes in the history of philosophy. However, it was never forgotten. This circumstance once again eloquently testifies to the real relevance and subject matter of disputes. The names of researchers we have listed are only a small part of the authors who not only recognize the nature of man, but also consider the physicality of man as a kind of indicator of the evolution of not only humanity, but of the entire socio-natural reality as a whole. It's A. Adler, J. Habermas, F. Mihina, Yves Charles Zarka, Griffith. James, W. Morgan), P. Teilhard de Chardin, M. K. Mamardashvili, E. Norbert, J. Huizinga, Jacques le Goff . V. A. Podoroga, V. P. Zinchenko, F. Bacon, T. Alkemeyer, K. Eisenberg and others.

Mihina F. the article "Human Nature - One of Anthropological Insolubilia?" criticizes those authors who do not recognize the existence of human nature in principle. In his opinion, something strange is happening in modern philosophy: many philosophers do not seem to believe that there is such a thing as human nature. The concept of "human nature", problems with its definition in the past and present of philosophical thinking and in academic traditions represent and form the intention of the author of the study. The author's efforts are to define the characteristics of the term in a broad arc of historical and philosophical thinking through its elected representatives. One of the ways to build a philosophy of life, a philosophy of the possible future, a strategy to ensure the continuity of human history is a philosophical and specifically scientific study of the person himself, the desire to understand the nature of man. Historically, this is where we find ourselves in a special situation - countless attempts to characterize human nature, despite their huge number, do not lead to any conclusion, at least so far they have not been successfully completed. Despite everything, the author based his speculcations on the belief that this problem is worthy of discussion (MIHINA, 2019).

Yves Charles Zarka in the article "Does the Concept of Human Nature Still Make Sense?" claims that when we turn to the phenomenon of human historicity, we must inevitably examine the concept of human nature, since it seems that historicity excludes the idea of historical or transhistorical human nature. In this article, the author, on the one hand, examines the extent to which the consideration of human historicity can lead to doubts about the concept of human nature, and on the other hand, examines the question of whether human nature has retained its significance, despite the harsh criticism that it has faced. From the very beginning, it should be noted that the concept of human nature has existed since the 19th century. The purpose of criticism of most scientific disciplines is not only in the context of thinking that 
overestimates the history of mankind. This criticism clearly took the form of a challenge to this philosophical concept.

Let's look at the philosophical aspects of this concept. Marx has an important position on the question with which we are dealing. But not everything is as clear as it may seem. He studied the history of companies, or rather their relationship to another, i.e. from one social form to another. From this point of view, man is a historical being, on the one hand, because of his material existence, and on the other - the forms in which he imagines his existence and the world. It seems historical to consider the dimension of man in the structures of his social existence. It causes a complete failure of the idea of a nature that would go beyond this story. All the more so because of the prospect of a proletarian revolution, thanks to which the people will break free from exploitation and class domination. It should provoke a resurgence incomparable to the changes that have occurred in the past, pushing this past into prehistory and opening up the real story. In other words, man is a developing being who gets by himself only for himself in history and in history, and not on the basis of historical nature, which would ultimately define it from the very beginning. We may, however, ask whether there are no ideas in the work of the young Marx, especially in the manuscripts of 1844, which are a prerequisite for the idea of alienation as a result of the alienation of labor. In other words, in addition to these texts from the youth, the idea of a classless society that should emerge from the opposites of capitalism and from the revolution of the proletariat, in a sense, this implies the opening of itself to a radically new world, but in another sense, for Marx and Engels, this world also represents a new discovery of primitive society, which was also a classless society. This, finally, was the reason why Walter Benjamin saw the creation of this society as a secular form of redemption, of forgiveness, not of original sin, but of the formation of a class. If this is the case, then the result of the story will be the return of the person to himself. In itself, that is, at least something like its nature.

Nietzsche's critique of human nature is much more radical. For Nietzsche, man is an unnatural thing, a disease that must be diagnosed in terms of the struggle of forces that permeate him and, in general, permeate their entire life. And at the same time, in terms of the values created by the antagonism of these forces and the domination they establish. The criticism is not historical, but genealogical. Man, as we know him, is a product of the morality of resentment-a Christian morality that must be destroyed, ruined, in order to receive the free flow of the will. Of course, thanks to morality, resentment and its values, a person has become interesting, but also tragically weak and sick. Overcoming man, too man, is the goal of rethinking all values, especially good and evil. This is the idea of the Übermensch, which 
presupposes a rebirth to the man beyond. In this context, the idea of an irresistible human nature can be considered a product of the morality of resentment, which seeks to resist the full expansion of life and the creative forces that affect life. From the idea of human nature only its designation as a philosophical instrument for the naturalization of human diseases remains here.

There is a connection between the statement that God is dead and the statement that man is dead, it is just its correlate. In the twentieth century, one of the most radical attacks on the idea of human nature and Heidegger's humanism occurred: Dasein is built on the destruction of the idea of human nature. Heidegger's attitude will be decisive not only for the entire philosophy of the second half of the 20th century, but also for all the Humanities and social Sciences. Dasein, literally being here, denotes this being that we are and that is related to ourselves, to others, and to the world - why is it in its existence as such a question of its being. Human nature does not exist, it is thrown into this world, a being without a reason. The existential structures that define it do not matter (ZARKA, 2018).

\section{Summary}

In the views of N. Elias and other authors, at first glance, it seems that some of the questions here are based on incorrect assumptions. Is it only in modern societies that people first began to enjoy sports? Didn't people play football in England and other European countries during the middle Ages? Did not the courtiers of Louis XIV have their own tennis courts and enjoy this" game of palms " (jeudepaume)? And before all the ancient Greeks, the great initiators of "athletics" and other "sports" - did not they, like us, organize local and international sports competitions on a Grand scale ? (ELIAS, 1971).

Isn't the resurgence of the Olympic games in our era a sufficient reminder of the fact that "sport" is not something new for us? It is difficult to answer the question whether the type of competition that was formed in England under the name "sport "and spread to other countries in the XVIII-XIX centuries was something relatively new, or whether it was a revival of something that was already among the Greeks, and that today we consider as"sport" in hindsight. The modern broad meaning of this word, encompassed by Norbert Elias, includes contests of any kind, which suggests the truth of the latter hypothesis (ELIAS, 1971). 


\section{Conclusion}

According to many researchers, the legacy of Enlightenment in the form of rationalism was overcome, remained in the past, in the XX century, the eyes were significantly turned towards irrationalism. This also affected the understanding of human nature, the statement about the significance of the bodily nature of man as a reliable, i.e. ontologically self-sufficient, trustworthy Foundation. According to J. Heising: "we know that not everything can be measured by the standard of reasonableness. The very progressive development of thinking has taught us that reason alone is not enough. A deeper and more versatile view of things than pure rationalism has given us an additional meaning in these things".

The new challenges of history persistently demand an answer from us. All questions eventually come to the "human" instance. What proportionality in human nature should be taken as correct and humane? "With the advent of new technologies, we reach the amazing body of "digital" disappearing. In fact, we are entering probably the most global anthropological crisis for which humanity, in my opinion, may not be ready. There are technologies that do not correspond in any way to the human body experience. Never before has a man encountered this. There was always a weak reference, but a man was always looking for compensation, constantly restoring the humanly.

Here we are faced with the neutral ideology of virtualism, the virtual world, which is absolutely devalued, it absolutely does not respond to the human... That is, absolutely, in no way distinguishes the human (ZINCHENKO; PODOROGA, 2004).

However, there are also unexpected and discouraging trends. If the certainty of the corporeal does not give us confidence in our understanding of human nature, are there any alternatives? B. G. Sokolov writes about the desire for self-confidence, lost along with the idea of God. This place in the social space is occupied by bodily practices with rational resources and goals. It's not even a sport in the classic sense. He calls it rational alignment in the field of bodybuilding - it is not only the internal organization of training methods. This is a whole industry, an industry that covers all areas of life. And in this regard, bodybuilding multiplies the technologies and ways of functioning of any sphere of modern life. The body can be completed. Culture can do this.

Here it is perfect physicality, satisfaction with your beauty! This is the illusion of your omnipotence: "the body becomes an authentic, authenticated identity. For it is rationally planned and created. Corporeality finally gets the desired status of intelligence, and reason- 
becomes not an ideal activity of consciousness, but a deed-action, as Fichte would say" [7]. Well, one more step towards yourself is passed...

ACKNOWLEDGEMENTS: The work is performed according to the Russian Government Program of Competitive Growth of Kazan Federal University.

\section{REFERENCES}

BOURDIEU, P. Kak mozhno byt' sportivnym bolel'shhikom? [How can I be a sports fan?]. Logos, n. 6, p. 99-113, 2009. Available: http://ecsocman.hse.ru/text/30790017.html. Access: 25 fev. 2020.

BUBLIK, P. I. Chelovekorazmernost' kak posil'nost' social'nogo opyta. [Human dimension as the power of social experience.] 2006. Available:

http://netgorod.narod.ru/articls/Bublic_4elovekorazmernost.htm. Access: 25 fev. 2020.

ELIAS, N. The genesis of sport as a sociological problem. The sociology of sport: A selection of readings, p. 88-115, 1971.

GRIFFITH, J. Thinking descartes in conjunction, with merleau-ponty: the humanbody, the future, and historicity (original title: thinking descartes in conjunction, with merleau-ponty: the human body, the future, and historicity). Filozofia, v. 74, n. 2, p. 111-125, 2019.

Available: http://www.klemens.sav.sk/fiusav/filozofia/?q=en/filozofia.2019.74.2.3. Access: 25 fev. 2020.

HUIZINGA, Y. V Teni zavtrashnego dnja. [In the shadow of tomorrow]. Available: http://booksonline.com.ua/review.php?book=157235. Access: 25 fev. 2020.

MAMARDASHVILI SENOKOSOV, M.Y. Strela poznanija. Nabrosok estestvennoistoricheskoj gnoseologii [The arrow of knowledge. Sketch of the natural history of epistemology] 2018. Available: https://books.google.ru. Access: 25 fev. 2020.

MAMARDASHVILI, M. K. Kartezianskie razmyshlenija [Cartesian reflections]. 2002.

MIHINA, F. Human nature: one of anthropological insolubilia? Filozofia, n. 4, p. 318-333, 2019.

MORGAN, W. Filosofija sporta Istoricheskij i konceptual'nyj obzor i ocenka ee budushhego. [Phylosophy of sports. Historical and conceptual review and assessment of its future] Moscow: Logos 3, 2006.

PHILOSOPHICAL readings. Saint Petersburg: Azbuka-klastika. 2002. 832 p. [Electronic resource]. Available:

http://yanko.lib.ru/books/philosoph/mm=phil readings=ann.html\# Toc84078707. Access: 25 fev. 2020. 
SAYKINA, G. K. The metaphysics of man as an area of "purified" humanity. Asian Social Science, v. 10, n. 21, p. 122-127, 2014. Available: http: // www. scopus.com/inward/record. url? eid=2-s2. 0-84908318595\&partnerID=40\&md5=538859c16d469506f1 de3c8a82bdc0e3. Access: 25 fev. 2020.

SOKOLOV, B.G. «Dumaj!»: telo ["Think!": body] (2001) Series " Symposium”, Russian mass culture of the end of the XX century. Saint Petersburg: Saint Petersburg Philosophical Society, 2011. 156 p. Available: http://anthropology.ru/ru/text/sokolov-bg/dumay-telo. Access: 25 fev. 2020.2011.

ZARKA, Y. C. H. Does the Concept of Human Nature Still Make Sense? Filozofia, 2018, v. 73, n. 10, p. 777-789, 2018. Available: http://www.klemens.sav.sk/fiusav/filozofia/?q=en/maeste-pojem-ludska-prirodzenost-zmysel. Access: 25 fev. 2020.

ZINCHENKO, V. P.; PODOROGA, V. Psihologija na kacheljah mezhdu dushoj i telom. Fenomenologija telesnosti [Psychology on a swing between the soul and the body". "Phenomenology of corporeality]. About the human soul and flesh: from speeches at the scientific and practical conference in Moscow state University "Interdisciplinary problems of psychology of corporeality, 2004. [Electronic resource]. Available:

https://cyberleninka.ru/article/n/o-chelovecheskoy-dushe-i-ploti-iz-vystupleniy-na-nauchnoprakticheskoy-konferentsii-v-mosgu-mezhdistsiplinarnye-problemy-psihologii. Access: 25 fev. 2020.

\section{How to reference this article}

IBRAGIMOVA, Z. Z. Physicality as a possible key to understanding human nature. Rev. EntreLínguas, Araraquara, v. 7, n. esp. 1, p. 162-172, fev. 2021. e-ISSN: 2447-3529. DOI: https://doi.org/10.29051/el.v7iEsp1.14885

Submitted: $28 / 10 / 2020$

Required revisions: $19 / 12 / 2020$

Approved: $13 / 01 / 2021$

Published: 28/02/2021 